\title{
A 5-year Retrospective Study on Alopecia in a Tertiary Hospital in Southern Nigeria
}

\author{
*Madubuko C.R and Okwara B.U
}

\begin{abstract}
Background: Alopecia is a common condition accounting for the top ten morbidities seen in patients that present at dermatology outpatient clinics in Nigeria.

Aim: This retrospective study aimed at documenting the prevalence and types of alopecia in the skin clinic at the University of Benin Teaching Hospital between December 2014 and December 2019.

Methods: The medical records of all patients with alopecia attending dermatological outpatient clinic between December 2014 to December 2019 were analyzed retrospectively for this descriptive observational study. An approval for the study was obtained from the Ethics Committee of the University of Benin Teaching Hospital, Benin-city, Nigeria. The diagnosis of Hair loss was essentially clinical, confirmed where expedient with a skin biopsy. Dermatological tools like Dermoscopes were also used to boost diagnostic accuracy when necessary. The patients were also evaluated for presence of other cutaneous and systemic disorders.
\end{abstract}

Results: During the 5year study period, 106 patients with hair loss $(6.6 \% \%)$ were observed. The youngest patient was 2 months old and the oldest patient was 90years old. The males constituted $61.3 \%$ of patients observed while the females accounted for $38.7 \%$ of patients seen. The male to female ratio was 1.6:1. Discoid lupus erythematosus of the scalp, was the most common disorder 29(29.4\%). Alopecia areata occurred in 23(27.7\%); tinea capitis in 15(14,2\%); Acne keloidalis nuchae in 14(13.2\%); seborrheic dermatitis10(9.4\%); and folliculiltis delcavans $9(8.5 \%)$. Less commonly observed causes of alopecia included androgenetic alopecia 2(1.9\%); traction alopecia 2(1.9\%); lichenplanopilaris $1(0.9 \%)$ and nevus sebaceum $1(0.9 \%)$.

Conclusion: There is a need for studies to further describe and proffer solutions to common causes of alopecia in our community.

Keywords: Retrospective study, Alopecia, Tertiary hospital, Benin

\author{
*Corresponding Author \\ Madubuko C.R \\ http://orcid.org/0000-0002-9155-4257 \\ E-mail: rolimadubuko@yahoo.com
}

Consultant Physician and Dermatologist, Department of Medicine, University of Benin

Teaching Hospital, Benin city 


\title{
Une étude rétrospective de cinq (5) ans sur l'alopécie dans un hôpital tertiaire du Sud au Nigéria
}

\author{
*Madubuko C.R and Okwara B.U
}

\section{Résumé}

Contexte général de l'étude: L'alopécie est une condition de classement courante qui explique les dix principales morbidités observées chez les patients qui se présentent dans des cliniques externes de dermatologie au Nigéria.

Objectif de l'étude: Cette étude rétrospective visait à documenter la prévalence et les types d'alopécie à la clinique externe de dermatologie de l'hôpital universitaire du Bénin entre décembre 2014 et décembre 2019.

Méthode de l'étude: Il s'agissait d'une étude rétrospective de patients présentant principalement une perte de cheveux. Les données ont été obtenues à partir des dossiers cliniques et des notes cliniques des patients.

Résultats de l'étude: Au cours de la période d'étude de 5 ans, 106 patients sur 1600 personnes fréquentant la clinique de la peau ont eu une perte de cheveux constituant une prévalence de $6,6 \%$. Les patients vus étaient âgés de 2 mois à 90 ans. Plus d'hommes (61,3\%) que de femmes (38,7\%) ont été vus; avec un rapport de 1,6: 1. Le lupus érythémateux discoïde du cuir chevelu était le trouble le plus courant «insérer un nombre absolu» $(29,4 \%)$. L'alopécie areata est survenue en «insérer le nombre absolu» 27,7\%; tineacapitis en «insérer le nombre absolu» 14,2\%; Acné keloidalisnuchae en «insérer le nombre absolu» 13,2\%; dermatite séborrhéique «insérer le nombre absolu» 9,4\%; et folliculiltisdelcavans «insérer le nombre absolu» 8,5\%. Les causes d'alopécie moins fréquemment observées comprenaient l'androgénétopécie $(1,9 \%)$; alopécie de traction (1,9\%); lichenplanopilaris $(0,9 \%)$ et naevus sébacé $(0,9 \%)$

Conclusion: Des études sont nécessaires pour décrire et proposer des solutions aux causes courantes d'alopécie dans notre communauté.

Mots-clés: Alopécie, lupus érythémateux discoïde, alopéciaareata, acné keloidalisnuchae

\author{
*Corresponding Author \\ Madubuko C.R \\ http://orcid.org/0000-0002-9155-4257 \\ E-mail: rolimadubuko@yahoo.com
}

Consultant Physician and Dermatologist, Department of Medicine, University of Benin

Teaching Hospital, Benin city 


\section{INTRODUCTION}

The usefulness of the human hair in view of social interaction and sexual attraction is enormous. Thus, hair loss and other structural defects of the hair shaft are associated with a reduced sense of self-worth which may result in psychological problems and withdrawal from social interims $(1,2)$.

Alopecia was a major reason why blacks in America visited a skin specialist. It was observed in $8.3 \%$ of patients in an African American study on scalp hair loss (3).

Alopecia can be grouped broadly into diffuse, pattern and focal hair loss. It may also be classified into cicatricial (scarring) and non-scarring forms. Scarring alopecia is characterized by permanent damage of the stem cell structure of the hair follicle (4). The net effect of this damage is the loss of hair production. In non-cicatricial alopecia on the other hand, the hair follicles are not completely destroyed so hair regrowth follows hair shedding. Cicatricial alopecia comprise a wide range of scalp disorders which result in permanent hair loss (5). They can be broadly classified into primary and secondary scarring alopecia. The primary form refers to a group of idiopathic inflammatory disorders, characterized by a folliculocentric inflammation that ultimately destroys the hair follicle (7). The secondary form results from almost any inflammatory process of the scalp that injures the skin and skin appendages (8). Regardless of which form, all scarring alopecia are defined clinically by the loss of follicular ostia and histologically by the replacement of hair follicles with fibrous tissue (9), 10). Studies on alopecia and causes in our locality are scarce. This study seeks to explore the prevalence and types of alopecia amongst patients who presented to the dermatology clinic in the University of Benin Teaching Hospital between December 2014 and December 2019. This will go a long way to add to the wealth of knowledge already existing especially within the southern part of Nigeria.

\section{AIM}

The aim of this study was to document the prevalence and types of alopecia seen in the University of Benin Teaching Hospital (UBTH) between December 2014 and December 2019

\section{MATERIALS AND METHODS}

A retrospective descriptive study was carried out for all newly diagnosed patients with hair loss that were seen between December 2014 - December 2019. The skin clinic is a tertiary health care institution that receives referrals from all parts of Edo and Delta state in Nigeria.

The medical records of patients were retrieved after getting an approval from the institution's ethical committee. Data extracted from patients' clinical records included the socio-demographic characteristics, general physical examination findings, scalp examination findings including demoscopic evaluation where necessary to boost diagnostic accuracy and the final clinical diagnosis. Investigations documented were also assessed. These investigations included scalp biopsy, scalp scrapings for fungal studies, hormone profiling for patients with androgenetic alopecia and serology tests like Antinuclear antibodies and anti-dsDNA antibodies for patients with discoid lupus erythematosus.

All data generated were analyzed using statistical package for social sciences (SPSS) version 21.0. Results were presented in tabular form. Discrete variables were presented as frequency and percentages. Continuous variables were presented as mean and standard deviation.

\section{RESULTS}

One thousand six hundred new cases were seen in the dermatological outpatient clinic over a 5year period between December 2014 and December 2019. One hundred and six (106) of these patients presented with scalp hair loss (alopecia). The prevalence of alopecia in this study was $106(6.6 \%)$.

The total number of males presenting with alopecia was $65(61.3 \%)$ while the females were $41(38.7 \%)$. The male to female ratio was 1.6:1. The mean age of patient presenting with alopecia was $29.4 \pm 14.5$ years while the age range was from 2 months -90years.

The age group that had the highest frequency of alopecia was 20-39yrs accounting for $62(58.5 \%$ ) of patients presenting with a history of hair loss. The extent of alopecia was diffuse in 5(4.7\%) and focal in $101(95.3 \%)$. The type of alopecia was scarring in $53(50 \%)$ and non-scarring in 53(50\%). 
Table 1: Socio-demographic data of

study population

\begin{tabular}{ll}
\hline Parameter & $\begin{array}{l}\mathbf{N}=\mathbf{1 0 6} \\
\mathbf{n}(\mathbf{\%})\end{array}$ \\
\hline $\begin{array}{l}\text { Age } \\
\text { Mean } \pm \text { SD }\end{array}$ & $29.4 \pm 14.5$ years \\
Age group & \\
0-19years & $23(21.7)$ \\
20-39years & $62(58.5)$ \\
40-59years & $17(16.0)$ \\
60-79 & $3(2.8)$ \\
$80-99$ & $1(0.9)$ \\
Sex & \\
Female & $41(38.7)$ \\
Male & $65(61.3)$ \\
Type of alopecia & \\
Scarring & $53(50.0)$ \\
Non scarring & $53(50.0)$ \\
Extent of alopecia & \\
Diffuse & $5(4.7)$ \\
Focal & $101(95.3)$ \\
\hline
\end{tabular}

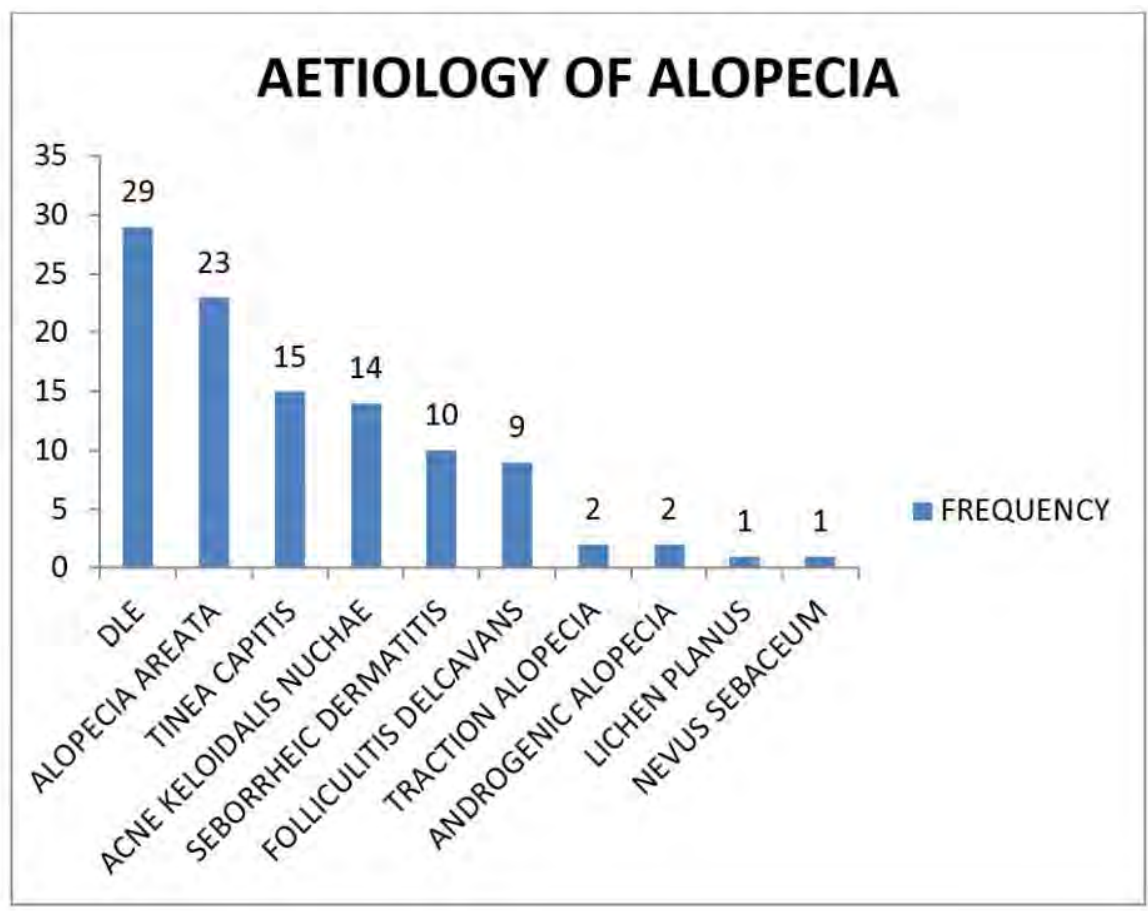

Figure 1: Aetiology of alopecia 


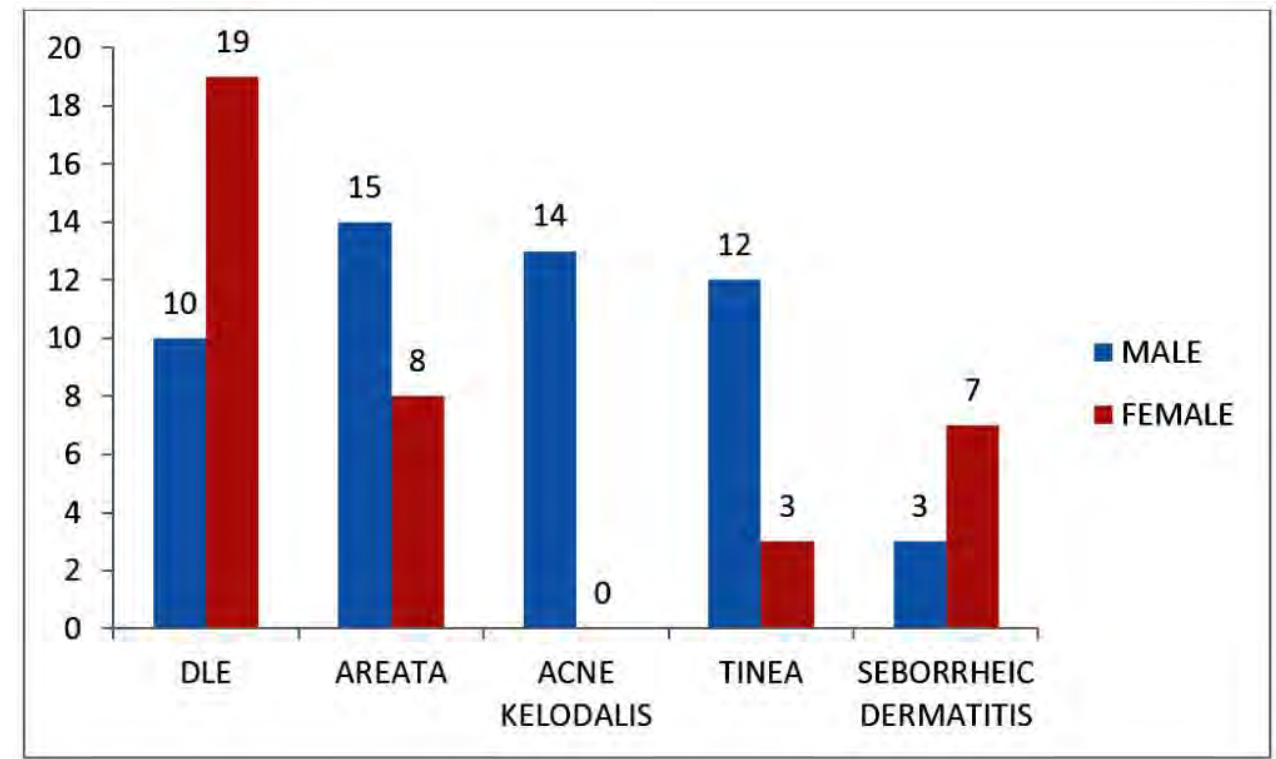

Figure 2: Relationship between gender and causes of alopecia

P values: Discoid lupus erythematosus (DLE) 0.00; Areata 0.67;

Acne kelodalis nuchae $0.001 *$; Tinea capitis 0.11 ; Seborrheic dermatitis $0.03^{*}$

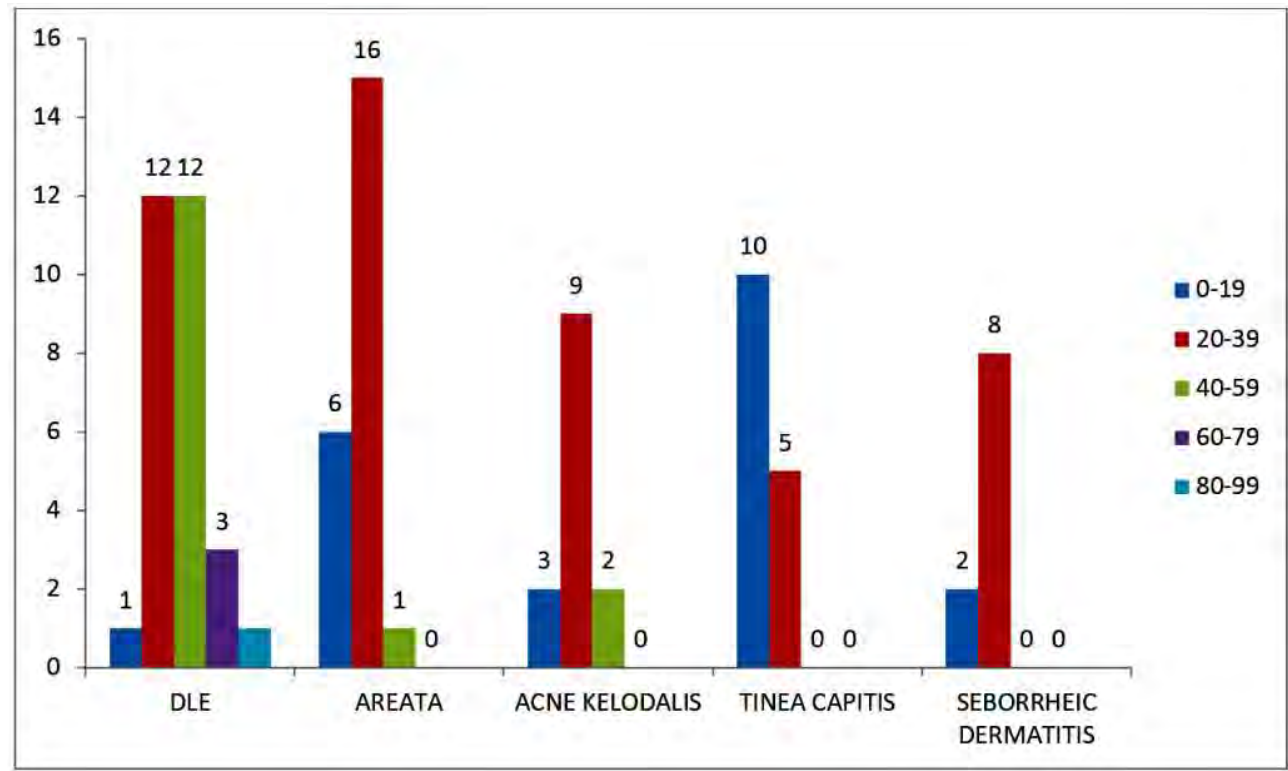

Figure 3: Relationship between age group and common causes of alopecia

P values: Discoid lupus erythematosus (DLE) 0.00*; Areata 0.34; Acne kelodalis nuchae (PFKN) 0.95; Tinea capitis $0.00 *$; Seborrheic dermatitis 0.55

The specific cause of alopecia included Discoid lupus erythematosus (DLE) 29(27.4\%), Alopecia areata $23(21.7 \%)$, Tinea capitis $15(14.2 \%)$, and acne keloidalis nuchae $14(13.2 \%)$. Others are seborrheic dermatitis $10(9.4 \%)$, folliculitis delcavans $9(8.5 \%)$, androgenic alopecia $2(1.9 \%)$, Traction alopecia $2(1.9 \%)$, lichenplanopilaris $1(0.9 \%)$; and nevus sebaceum $1(0.9 \%)$ in a descending order of frequency.

\section{DICUSSION}

The hair confers an alluring charm to an individual, thus boosting self-confidence and self-worth. In recent times, the African hair has become a thing of pride, women now seek to keep their hair natural, stopping previous hair practices such as relaxers that was once considered the best form of hair look. One of the unique features of African textured hair is its ability to be sculpted and molded into various shapes and forms. Hence, while hair may play an important 
role in the lives of people of all races, for people of African descent, this role is amplified due to the unique nature and texture of Black hair. Since antiquity, Black hairstyles have been known for their complexity and multifaceted nature, a notion that remains true today (11). Alopecia is quite common ranking among the top ten morbidities seen in patients that present at dermatology outpatient clinics in Nigeria (12).

It becomes expedient to explore the causes of alopecia in our locality, thus procuring possible solutions and contributing to the wealth of knowledge already existing. The prevalence of alopecia in this study was 106(6.6\%).

Alopecia occurred more commonly in males in our study 65(61.3\%). The male preponderance of scalp and hair disorders may be reflective of high prevalence of disorders such as acne folliculitis/keloidalis nuchae, and folliculitis decalvans, which are chronic inflammatory disorders found mostly in males of African descent $(3,13)$.

This study showed that Discoid lupus erythematosus (DLE) was the most common cause of alopecia constituting 29(27.4\%) of hair disorders seen. It occurred mostly in the age groups $20-39$ years and $40-59$ years. Alopecia areata, Acne keloidalis nuchae, tinea capitis and seborrheic dermatitis followed in a decreasing order of frequency. This finding was quite similar to the work done by Ayanlowo where she found alopecia areata to be the second most common cause of alopecia (1). Tinea capitis as a cause of alopecia was quite common in this study. A comparable observation was seen in a study done in Southeastern Nigeria by Nnoruka where tinea capitis was the most predominant scalp problem found amongst children followed by Alopecia areata, psoriasis and telogen effluvium (12).

However, Sarifakioglu in Turkey reported seborrhoeic dermatitis, transient neonatal hair loss and alopecia areata as the most predominant scalp and hair diseases in children (14). Tinea capitis and seborrheic dermatitis also occurred frequently in our study.

Discoid lupus erythematosus can be seen in several areas on the skin; however, the most frequent site of occurrence is the scalp. It was attributed as the cause of alopecia in $30 \%-50 \%$ of reported cases of scalp hair loss $(15,16,17)$. Initially in DLE, the lesions are not scarring but there may be mild inflammation $(18,19)$. This soon progresses overtime to irreversible cicatricial alopecia, occurring in $60 \%$ of persons with DLE $(20,21,22)$. There were more females $19(65.5 \%)$ with scalp DLE in our study. This is comparable to other studies (17, $18,22)$.

There is no gender preference in the development of scarring in DLE (17). Both males and females are equally susceptible to scarring as the disease progresses. Scarring is an indication of a poor prognosis as such patients will usually have a protracted course of disease $(17,23)$.

Alopecia areata was noted in $23(21.7 \%)$ of patients in our study. It constituted the second most common cause of alopecia in our study which is in keeping with surveys by Ayanlowo (24). While equal sex distribution was reported from other parts of the world (24); this study found a male predilection, though not a statistically significant finding. Alopecia Areata (AA) occurred most frequently in the third and fourth decade in our study with $95.7 \%$ of cases occurring in persons less than 40years. Our findings were comparable to published reports. The triggers for alopecia areata include proinflammatory agents, diet and stress $(25,26,27)$.

Tinea capitis was observed as a cause of focal hair loss in 15(14.2\%) of persons with hair loss in this study. It occurred more frequently in males; however, this finding was not statistically significant. The most affected age group was 0 - 19years accounting for $66.7 \%$ of persons with tinea capitis. This finding is in keeping with documented studies where Tinea capitis is said to be seen more commonly in the younger population, usually in males less than 20years of age $(28,29)$.

Acne keloidalis/folliculitis nuchae was reported in $14(13.2 \%)$ of persons with alopecia in our study. It occurred only in males and was most frequently seen in 20 - 39years age group. This is comparable to documented works where acne keloidalis is estimated to be observed more frequently in African males during their $3^{\text {rd }}$ to $5^{\text {th }}$ decades $(15,17,19)$.

It is important to note that females have been documented to be affected in a few studies $(20,21)$. This primary cicatricial alopecia aetiology is unknown however, trauma (shirt collars) and infection (desmodex and bacteria) have been implicated. Histologically, the lesions are characterized by an acute inflammation composed of lymphocytic and neutrophilic infiltration. 
Furthermore, there is chronic granulomatous inflammation around the isthmus and the inferior part of the infundibulum (8).

Seborrheic dermatitis occurred in 10(9.43\%) of the patients. It occurred more commonly in females. It generally occurs in the sebum-rich areas like the trunk, face and scalp. In scalp affectation, it is usually referred to as dandruff in mild cases but may manifest as exfoliative erythroderma in severe cases (30). The exact pathophysiology remains unclear however, an abnormal immune response in the presence of normal levels of malassezia species have been implicated. In addition, helper $T$ cells and antibody titres are usually depressed in this condition (31).

Folliculitis delcavans, traction alopecia, androgenic alopecia, lichen planopilaris and nevus sebaceum constituted the remaining hair loss related disorder seen in this study. Traction alopecia occurs when prolonged hair traction results in transient hair loss but if the process continues overtime, follicular atrophy and permanent scarring occurs. Common causative factors include; tight pony tails, braids, extensive use of rollers and persistent use of chemical relaxants. Traction alopecia in the frontal hairline is frequently seen in Sikh men, whose hair is usually tight up in a "top knot" confirming the fact that tight hair styles are a major contributory factor to this type of alopecia $(4,9)$.

Androgenetic alopecia or pattern hair loss, is a very common cause of hair loss in both men and women. It is an androgen dependent and genetically determined trait. It is characterized by a progressive decline in the anagen phase of hair growth and an increase in the duration telogen phase of the hair cycle. There is also associated miniaturization of scalp hair follicles. In women, androgen excess and polycystic ovarian syndrome may be implicated. There may also be associated hirsutism, acne conglobata and difficulties in achieving conception in them (6).

\section{LIMITATION OF STUDY}

The study may not reflect exact attributes of general population due to its retrospective, observational, hospital-based and cross-sectional nature.

\section{CONCLUSION}

Discoid lupus erythematosus, alopecia areata and acne kelodalis were common causes of alopecia seen in our study while androgenetic alopecia, traction alopecia and central centrifugal cicatricial alopecia, were uncommon contrary to our expectation. Studies to proffer solutions to common causes of alopecia will be required in the future. Also, community-based studies at the grassroots should be encouraged to describe disorders of hair care practices like traction alopecia amongst persons that may never visit a dermatologist for evaluation.

\section{ACKNOWLEDGEMENT}

We wish to thank the management of the University of Benin Teaching Hospital for allowing us have access to patients' clinical records used in conducting this study.

Conflicts of interest: There are no conflicts of interest.

\section{REFERENCES}

1. Tosti A, Gray J. Assessment of hair and scalp disorders. J investing Dermatol Symp Proc. 2007; 12:23-27

2. Shapiro J, Price VH. Hair regrowth. Therapeutic agents. Dermatol Clin 1996; 16:341-356

3. Alexis AF, Sergay AB, Taylor SC. Common dermatologic disorders in skin of color: A comparative practice survey. Cutis 2007; 80:387-94.

4. Olsen E.A. Summary of North American Hair Research Society (NAHRS)-sponsored Workshop on cicatricial alopecia, Duke University Medical Center. J AM Acad Dermatol 2003; 48:103-110

5. Price VH. Treatment of hairloss. N Engl J Med 1999; 341:964-973

6. Otberg N, Finer AM, Shapiro J: Androgenetic alopecia Endocrinol Metab Clin North Am 2007; 36:379-398

7. Alkhalifah A, Alsantali A, Wang E, McElwee KJ, Shapiro J. Alopecia areata update: Part I. Clinical picture, histopathology, and pathogenesis. J Am Acad Dermatol 2010; 62:177-88.

8. Wiu WY. Diagnosis and management of primary cicatricial alopecia: Part 11. Skinned 2008; 7:78-83 
9. Olsen EA. Disorders of epidermal appendages and related disorders: Hair. In: Freedberg IM, Eisen AZ, Wolff K, Austen KF, Goldsmith LA, Katz SI, editors. Fitzpatrick's Dermatology in General Medicine. Ch. 71. USA: McGraw-Hill Medical Publishing Division, 2003; 633-55.

10. Otberg N. Diagnosis and management of primary cicatricial alopecia: Part 1 . Skinned 2008;7: 19-26

11. Chapman, Y. “I am not my hair! Or am I?": Black women's transformative experience in their self-perceptions of abroad and at home. Master's thesis 2007. http://digitalarchive. gsu.edu/anthro_theses/23

12. Nnoruka EN, Obiagboso I, Maduechesi C. Hair loss in children in South-East Nigeria: Common and uncommon cases. Int J Dermatol 2007;46 (Suppl 1):18-22.

13. Coley MK, Alexis AF. Dermatologic conditions in men of African ancestry. Expert Rel Dermatol 2009; 4:595.

14. Sarifakioglu E, Yilmaz AE, Gorpelioglu C, Orun E. Prevalence of scalp disorders and hair loss in children. Cutis 2012; 90:225-9.

15. Knable AL Jr., Hanke CW, Gonin R. Prevalence of acne keloidalis nuchae in football players. J AmAcad Dermatol 1997; 37:570-4.

16. George AO. Acne keloidalis at the University College Hospital Ibadan, Nigeria. Niger Med Pract 1994; 27:52-4.

17. Letada PR, Satter EK. Acne Keloidalis Nuchae. eMedicine Dermatology. Available from: http://www.emedicine.medscape.com/article/1 072149

18. Meffert J, Arffa R, Gordon Jr. R, Huffman RI, Law SK, Phillpotts BA et al. In James WD, editor. Psoriasis overview. eMedicine 2014. Available from: http://www. emedicine.medscape.com/article/1943419overview.

19. Adegbidi H, Atadokpede F, do Ango-Padonou F, Yedomon H. Keloid acne of the neck: Epidemiological studies over 10 years. Int $\mathrm{J}$ Dermatol 2005;44 (Suppl 1):49-50.

20. Ogunbiyi A, George A. Acne keloidalis in females: Case report and review of literature. J Natl Med Assoc2005; 97:736-8.

21. Dinehart SM, Tanner L, Mallory SB, Herzberg AJ. Acne keloidalis in women. Cutis 1989; 44:250-2.

22. George AO, Akanji AO, Nduka EU, Olasode JB, Odusan O. Clinical, biochemical and morphologic features of acne keloidalis in a black population. Int J Dermatol 1993; 32:7146.

23. Madke B, Khopkar U. Pediculosis capitis: An update. Indian J Dermatol Venereol Leprol 2012; 78:429-38.

24. Ayanlowo O.O. Scalp and hair disorders at Dermatology outpatient clinic of a tertiary hospital. Port Harcourt Medical Journal 2017; 11(3):123-33.

25. Martinez-Mir A, Zlotogorski A, Ott J, Gordon D, Christiano AM. Genetic linkage studies in alopecia areata. J Investig Dermatol Symp Proc 2003; 8:199-203.

26. McDonagh AJ, Tazi-Ahnini R. Epidemiology and genetics of alopecia areata. Clin Exp Dermatol 2002; 27:405-9.

27. Barahmani N, de Andrade M, Slusser J, Zhang Q, Duvic M. Interleukin-1 receptor antagonist allele 2 and familial alopecia areata. J Invest Dermatol 2002; 118:335-7.

28. Adefemi SA, Odeigah LO, Alabi KM. Prevalence of dermatophytosis among primary school children in Oke-Oyi community of Kwara state. Niger J Clin Pract 2011; 14:23-8.

29. Ayanlowo O, Akinkugbe A, Oladele R, Balogun $M$. Prevalence of tinea capitis infection among primary school children in a rural setting in South-West Nigeria. J Public Health Afr 2014; 5:349.

30. Groisser D, Bottone EJ, Lebwohi M. Association of pityrosporum orbiculare with seborrheic dermatitis in patients with AIDS. J AM Acad Dermatol 1989;20(1):770-3.

31. Odom RB. Seborrheic dermatitis in AIDS. J Int Postgrad med. 1990; 2:18-20 